\title{
OMAH ALAS AS AN ADAPTIVE DWELLING IN KARST AREA: SPATIAL CHARACTERISTICS
}

\author{
Shabrina Tamimi ${ }^{1^{*}}$, Dwita Hadi Rahmi ${ }^{2}$ \\ ${ }^{1}$ Department of Architecture and Planning, Faculty of Engineering, Universitas Gadjah Mada, Yogyakarta, Indonesia \\ ${ }^{2}$ Department of Architecture and Planning, Faculty of Engineering, Universitas Gadjah Mada, Yogyakarta, Indonesia
}

\begin{abstract}
The environmental condition of particular landscape contributes to the way of life of people living inside it. The characteristic of Gunung Sewu karst landscape in the south of Gunungkidul Regency causes the regular drought every year. The communities who live in the area, in which the majority of them work as traditional farmers, deal with such situations and gradually adapt to harmonize their lives with those conditions. In order to cultivate their land more intensively under the pressure of environmental conditions, the farmers build omah alas, a simple house to live around their field. Omah alas has characteristics as result of the relationship between people and landscape. This paper aims to identify the characteristics of omah alas as living space for traditional farmers in karst area, specifically in Kemadang Village, and the influencing factors. This research used qualitative approach and the data were collected by field observations and informant interviews. The results showed that there are three types of space layout that are caused by site conditions. The influence of spatial character is reinforced by economic motives.
\end{abstract}

\author{
ARTICLE INFO \\ Received 24 April 2020 \\ Accepted 03 June 2020 \\ Available online October 2020 \\ *Corresponding Author \\ Shabrina Tamimi, ST. \\ Universitas Gadjah Mada \\ Email: \\ shabrina.tamimi@mail.ugm.ac.id
}

\section{Keywords:}

spatial characteristics, traditional house, farmers house, Gunungkidul, karst landscape

\section{Introduction}

Dwelling, with its various physical forms, is basic need for human. Houses in various parts of the world will have different forms that adapt to the local culture. In long period of history, humans interact with nature and adapt to it. Along with it, they would build their living spaces to protect themselves and rest. For traditional societies, how houses are created tend to be balanced with the environment in which they live. In creating houses, traditional communities generally use natural resources more wisely due to the lack of modern technological intervention that accelerate environmental change. Therefore, they build houses by imitating what their predecessor had done.

Traditional societies in southern part of Gunungkidul regency live in karst area which called Karst of Gunung Sewu. The physical condition of landscape of Gunung Sewu shows that the land surface is covered by large number of hills, hence it is called gunung (mountain) and sewu (thousand). This area is known as an arid region, rocky land, and lack of water resources especially during the dry season.

In Gunung Sewu karst area, the majority of land use is for agriculture, and many people work as peasants or traditional farmer. The water scarcity makes them unable to have irrigation system so they only rely on rain water to cultivate their land. Especially in Kemadang Village, traditional communities carry out strategy to live in their rural area. In relation to the living place, they divide their dwelling in two places. In order to work in the land intensively, they build dwellings around their fields. These buildings, commonly referred to omah alas, is a simple house used for work purposes. Due to the distance between the fields and village settlements is quite far, omah alas is a separate house from the main house in village. Omah alas emerged as an adjustment for farmers to survive in difficult agricultural conditions. Lack of water source, hilly location, and limited resources are physical characteristics of the environment that make farmers struggle harder than people in irrigated fields. They work hard in cultivating land therefore they need a place to support their activities.

The intention of this paper is to identify the characteristics of omah alas and describe the influencing factors. The research is limited to the spatial aspects such as space utility, space arrangements, and orientation. 
Space aspect is chosen since human activities were accommodated first in space form ideas. In discussing dwelling form, spatial organization is the most fundamental and the most stable aspects compared to other aspects such as the style (related to the aesthetic form) and physical aspects (related to structure and material of the house) (Habraken, 1988).

\section{Literature Review}

\subsection{Dwelling}

Dwelling is place where everyday life takes place, and that daily life represents things that happen continuously in human existence (Schulz, 1985). This statement is emphasized by Wongphyat and Suzuki (2008) that dwelling is a physical manifestation of the multifarious whole between humans and our existential space, a traditional dwelling clearly reveals the image that manifests the "proximity", the micro cultural level of human existence.

Rapoport concluded that the relation of human and landscape would be an important aspect in the creation of house form and there are three classification of those relationships: 1) Religion and cosmological (man is less than nature); 2) Symbiotic (man and nature are in a state of balance); and 3) Exploitative (man tend to destroy) (Rapoport, 1969).

Many findings show that the appearance of houses is not only influenced by one single factor but there are many factors that must be taken into consideration. Traditional dwellings might respond to determinants such as ecological, economic, and cultural, but there is more multiple perspective that makes it possible to go beyond those deterministic approaches (Toffin, 1994). As Rapoport said socio-cultural factors take a primary role rather than physical forces in affecting house form. Socio cultural factors contain wide range of visions that people have of the ideal life while physical ones relate to climate, materials and technology, and site (Rapoport, 1969).

\subsection{Gunung Sewu Karst Landscape}

Karst is a unique condition of landscape which arises from a combination of high rock solubility; thus, porosity develops well (Ford and Williams, 2007). Such areas are characterized by water scarcity on the land surface, while below the surface, water is very abundant. This can occur because the conditions of land porosity can cause water to enter the underground water flow system directly (Fatchurohman et al., 2013). Therefore, water is mostly available underground while scarce on the surface. In fact, in Gunung Sewu Karst area, underground river is not readily accessed by local people due to its great depth (more than $100 \mathrm{~m}$ ) (Haryono et al., 2009).

Gunung Sewu Karst area stretches for about $1.300 \mathrm{~km}^{2}$, as far as $85 \mathrm{~km}$ from west to east with a width between 10$29 \mathrm{~km}$ from north to south (Haryono et al., 2017). People in Gunung Sewu karst recognize that their water resources tend to be influenced by the rock characteristic, which locally called watu gamping (carbonate rocks), that causes no surface river (Retnowati, 2014).

The surface of Gunung Sewu Karst area is characterized by hundreds of hills (conical hills) with an irregular pattern that has a height of up to 50 meters from the ground (Nibbering, 1995). Between the cone hills there are basins that are used for agricultural activities. Uhlig (1980) states that the surface of the basin is covered with red soil which is rich in nutrients so that it is useful for agricultural activities.

\section{Research Method}

This research was conducted in Kemadang Village, Tanjungsari sub-district, Gunung Kidul Regency, which is located in the karst area of Gunung Sewu. Using qualitative research methods, data were collected through field observation and interviewing the occupants. According to Habraken (1988) spatial system is related to how space is organized and arranged so that the variables used are the layout of space (including room scale and building scale) and house orientation. The primary data such as house floorplans were measured and documented in order to obtain a comprehensive picture of spatial condition of the house. Interview of residents was conducted to collect information about the motive behind the spatial arrangement as well as information of their daily activities to understand the space requirements.

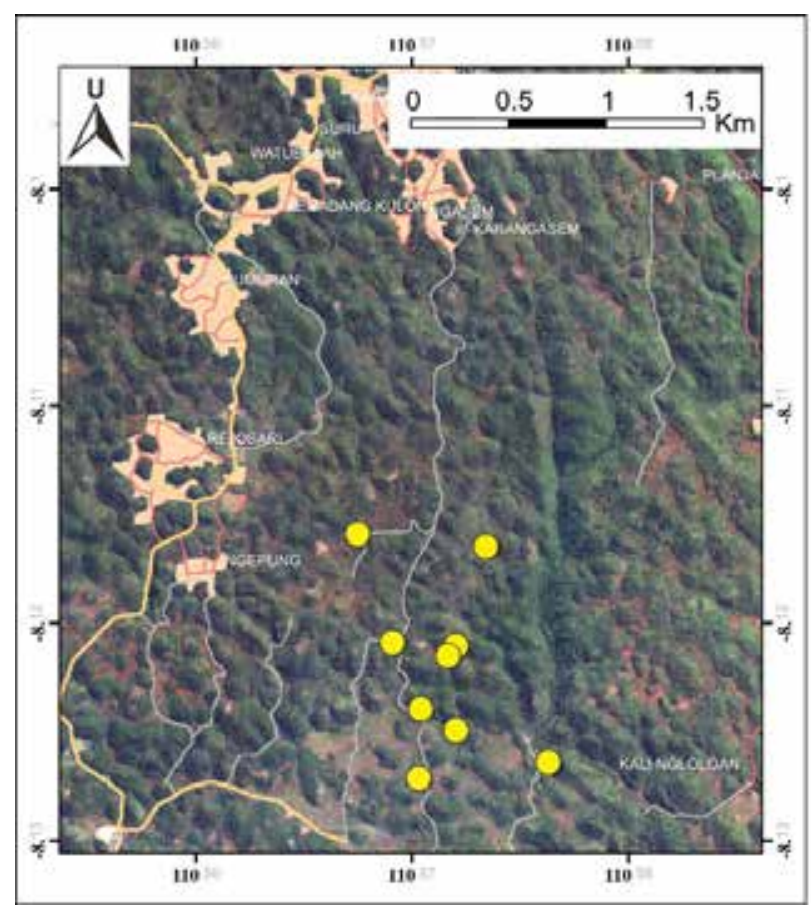

Over numerous omah alas which spread around the field area, nine houses were selected as there were used as main dwellings for farmers where they spend most of activities there. Houses location is scattered in alas, local term for fields and farms, which is located about $1,5-3 \mathrm{~km}$ via accessible road (figure 1). 


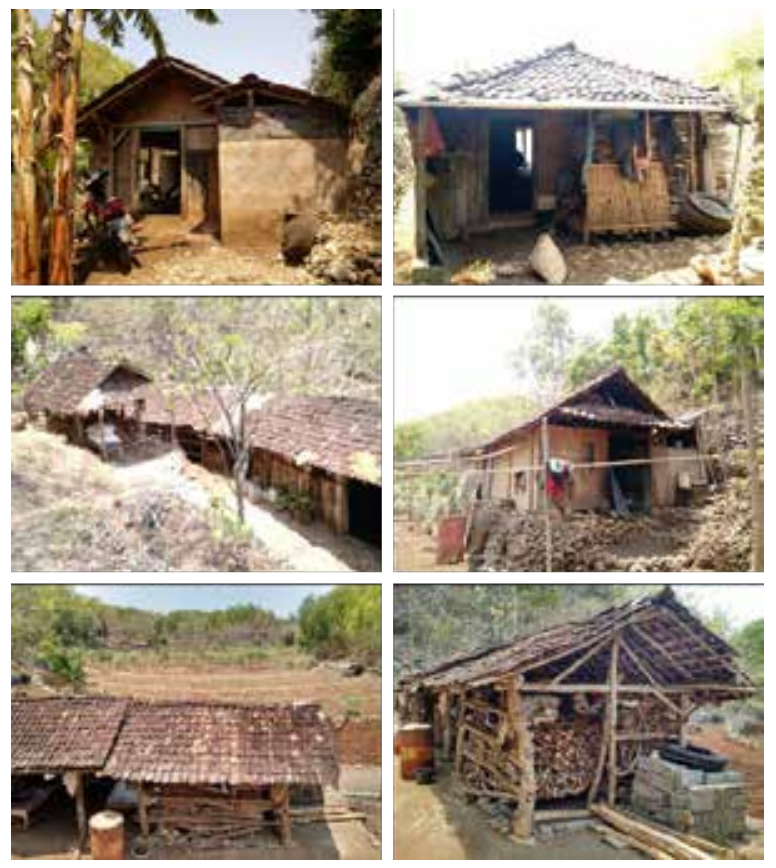

Figure 2. Omah Alas

Source: Author's Documentation, 2019

\section{Results and Discussions}

The main activities of farmers in alas are cultivating crop fields and taking care of their livestock. In managing fields, they tend to be busier in the rainy season in order to maintain the plants to grow well until the harvest season comes. Other than that, they do basic activities such as sleeping, cooking, and eating. It should be noted that all occupants of these 9 houses are people who chose to live in omah alas every day rather than their main house in the village. The main reason is most of them are in elderly age and find difficulties to move back and forth between field and the main village. Their children are mostly adults who are able to take care of the main house in village. Hence omah alas is inhabited by an elderly couple or even only one person. The other reason is they feel more comfortable near their own farm that they don't need to think anything other than working. They will return to the village only for important occasions that can't be left behind such as attending wedding ceremony or cultural events. For every 5 days or a week, they will go to village market to buy food supplies. The distance between one omah alas to another is far apart as it attached to each other's farmland, so omah alas is more of an individual place that stands alone, not many other people visit except for really important matters.

\subsection{Space Function}

Omah alas contain spaces that support daily life its occupant. The nine houses show that spaces in it consist of three main functions: 1) basic human activities, occur in the bedroom to rest/sleep, kitchen to cook or fireplace, and seating space in porch; 2) storage function, place to put life support objects such as rainwater tank, firewood, food stock, fodder, etc. 3) livestock hut, including cattle and goat. The types of house plan are illustrated in figure 4 .

Basic living activities are accommodated in sleeping and cooking areas. Both spaces can be in separate rooms and divided by partition or put together in one space so the bed and kitchen are in the same room. The sitting space is considered as a necessary area as all houses have this particular place. Sitting area is more like a multipurpose place where people can take leisure time, eat, meet guest and watch over their field. While kitchen and bedroom are in a closed space/indoors, sitting room is semi open space and similar to front porch/veranda which have direct view to the field.

Storage is an important part of the house and it is used to keep things that support occupant's life such as firewood, water, food supplies, as well as fodder or cow's food. Food supplies and firewood are often stored in kitchen but some goods need their own places. A huge pile of firewood with larger size is mostly placed outside the main house so it is easier to compile after collected from field. Water is stored in a huge tank with a capacity of approximately 5000 liters or even more in some houses. This tank keeps rainwater collected through the house roof during rainy season. With an average size of $3 \mathrm{~m} \times 4 \mathrm{~m}$ the tank water is expected to supply water use in dry season. Another thing that requires a lot of space is dry animal feed (thatch). When the dry season comes where green grass can't be found anywhere in field farmers will buy a large pile of thatch to supply cow's food. This requires one space with an average size of $2 \mathrm{~m} \times 3 \mathrm{~m}$ for one cow and will need more space for more cows.

Livestock hut is needed to protect animals such as cows and goats. These animals are regarded as an important asset that can be sold to fulfill sudden need. Cattle can be used to plow fields and its dung used to fertilize the soil. For that reason, livestock plays a very important role in farmer's lives. Some people have several cows and goats so the size of the hut depends on how much animals they have. The average proportion of space usage can be seen in figure 4.

It shows that of the three zoning divisions, the smallest average is space for live stocks, and the proportion of basic living space and storage space is similar, only difference of $4,8 \%$. However, if the ratio is between the space for the occupant's basic living activities and the space for other function then the space for basic living activities is still less. This means that the proportion of space that is actively used by the occupant has less proportion than passive space which is for storage and livestock. Of the overall houses, the area for basic living activities uses less than $50 \%$, except for house $\mathrm{H}$ and more than $50 \%$ of the area used as a combination of storage and livestock hut.

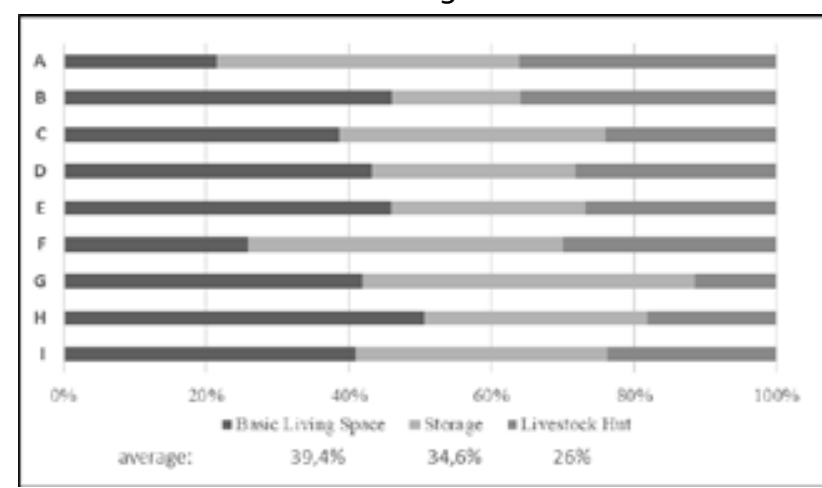

Figure 3. Proportion of Area for Each Space Function in Omah Alas

Source: Data Analysis, 2020 


\subsection{Space Function}

The basic shape of a single room in omah alas is square which is then arranged linearly along with other rooms. The sizes of the building are generally around 2,2 to 3 meters on the short side and 6 to more than twenty meters (depending on occupant requirements) on the longer side. The more space needed by the occupants, the longer the configuration of the house. However, if site conditions cannot accommodate the house to be in longer shape, the house will be divided into several separate units.

The nine cases show that the space arrangement pattern occurs in three types. Either it is formed in a single building or in a dispersed pattern. If it appears to be a dispersed pattern, the house is divided into two parts: bedroom, kitchen, and water tank are always in one building unit and livestock hut, firewood and cow's food storage are in another unit. The kitchen tends to be placed at the back area separated from the sitting area. The arrangement of space is related to the building mass composition. Type 1 is house in which the arrangement of the spaces is joined in one single unit (figure 4). In type 2 the space units are separated but still in relatively close positions. Type 3 is the development of type 2 where space units are separated into several units in which each unit is located in quite far position. Type 1 only consists of 2 houses (A \& B) as well as type 2 consists of 2 houses ( $C \& E$ ). While type 3 has the most cases, there are 5 houses $(D, F, G, H, I)$.

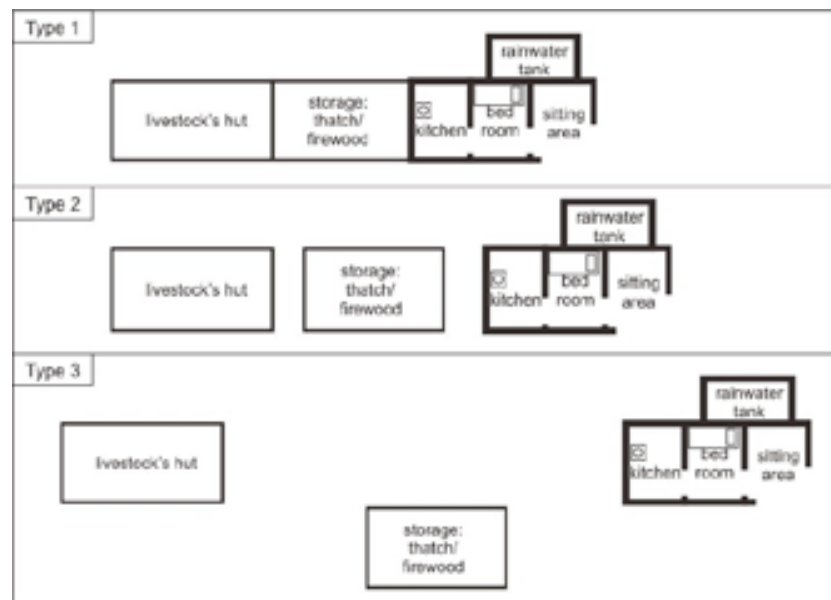

Figure 4. Type of house plan and function Source: Data Analysis, 2020

The position of omah alas tends to close to the crop field. The arrangement of space adjusts to the land condition. The karst landscape characteristics cause a crop field always surrounded by hills. Houses on the edge of the fields will automatically occupy foothill's part (figure 5). Although the nine houses are relatively at the foot part of the hill, there are variations in the distance between the house and the field, some are right next to the field with a distance about 0-5 meter (house A, B, C, E, I), some are a further away from 5 meters and slightly up to the middle of the hill (house D, F G, H). All of them are located in areas outside arable land so that the land for the base of the house tends to be rockier. They choose to build house outside of the arable field in order to maximize the planting area. In fact, sites at foothills tend to be narrow and uneven. Therefore, some houses are formed in a single unit of building on spacious site, whereas on limited space the house will be divided into several separate units. It also shows that the building layout is in line with the topography. The contour makes the area for house has elongated shape. Therefore, the shape of building would likely to fit with contour lines.

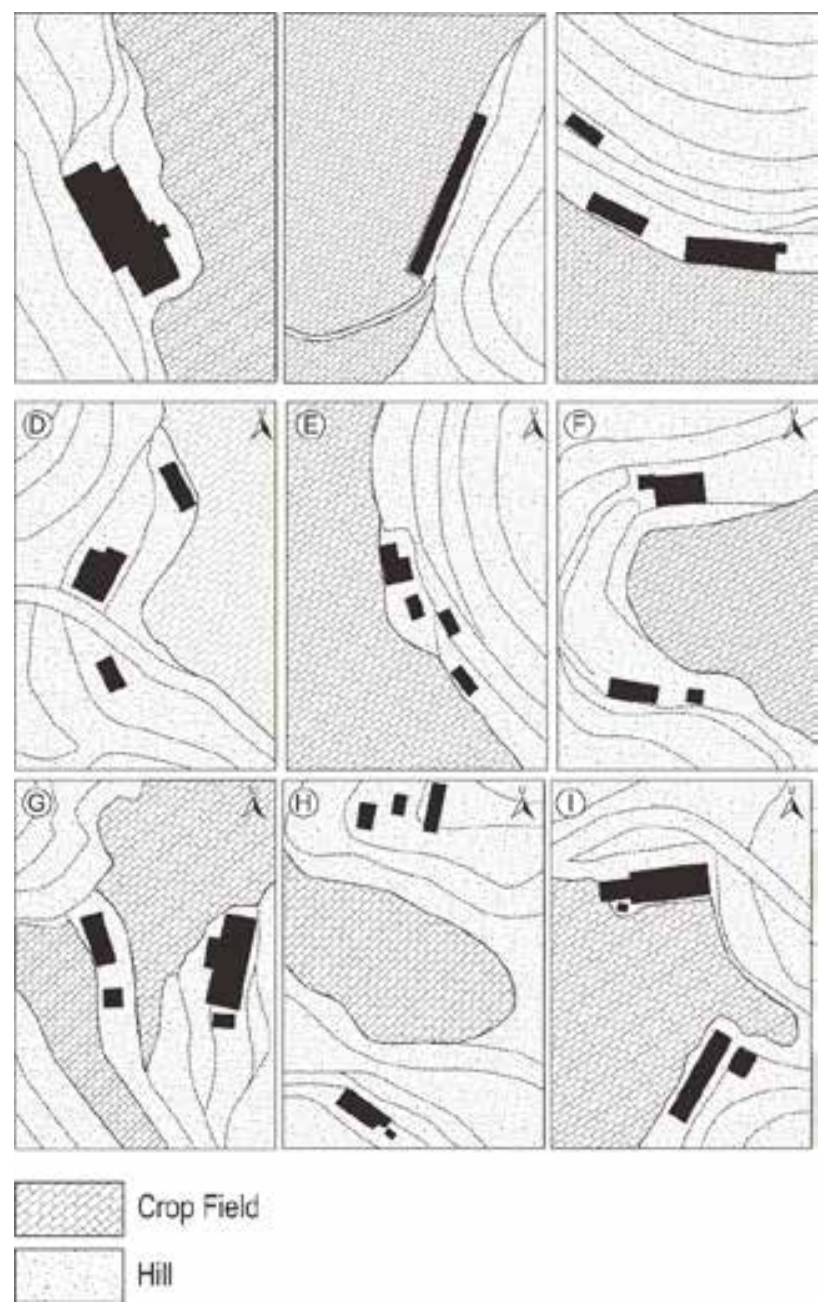

Figure 5. Dwellings position on the field. Each house is located next to the field and on the bottom part of the hill. The building shape tend to elongate along with contour line.

Source: Data Analysis, 2020

\subsection{Orientation}

The orientation of the houses shows in various types. It has been mentioned before that house's location is at the foothill right next to the field. Some houses can be accessed through the road with a width of around 2,5 meters, but most of them can only be accessed via small footpath as wide as 1 meter. The entrance of the house is in a varied position. Based on the linear shape of the house, the entrance can be on the edge side of the house or in the middle. So that the orientation of the house is not determined from the position of the entrance. However, of the 9 houses there are parts of the house that consistently face the same direction, that part is the sitting room which always has a side wall that opens to the fields (figure 6).

It is found in 6 houses (house $A, B, C, E, G, I$ ) whose sitting area has an open wall in certain side to have a direct view of the crop fields. Another 3 houses (House D, F, H) have the house position slightly higher than the field area so the 
sitting area can't really face directly to the field. The occupants need to watch over their field directly from inside their house so when something happens on their land, they can immediately inspect it.
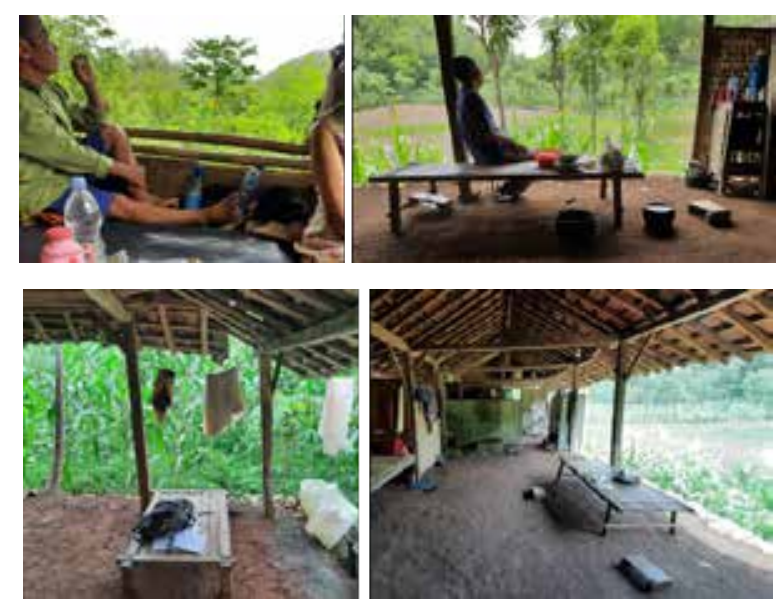

Figure 6. Farmers could watch over their field directly from sitting place

Source: Author's Documentation, 2020

\subsection{Relationship between spatial elements}

The data shows that overall houses in all 3 types have an area of $25-50 \%$ for basic living activities (sleeping, cooking, and resting), there are only 2 houses whose proportion of the area is outside this range (figure 7). Omah alas that has the least amount of living space area $(21,5 \%)$ was found in one house of type 1 houses and the most area for living space $(50,6 \%)$ was found in one house of type 3 . This means that neither houses with single pattern spatial arrangement, multiple units in one location, and multiple units in separated location, don't show a significant difference in the proportion of the area for living space. Although three types of houses show different spatial layout, the proportion of the area of space for living activities in most of houses remains the same in the range of $25-50 \%$.

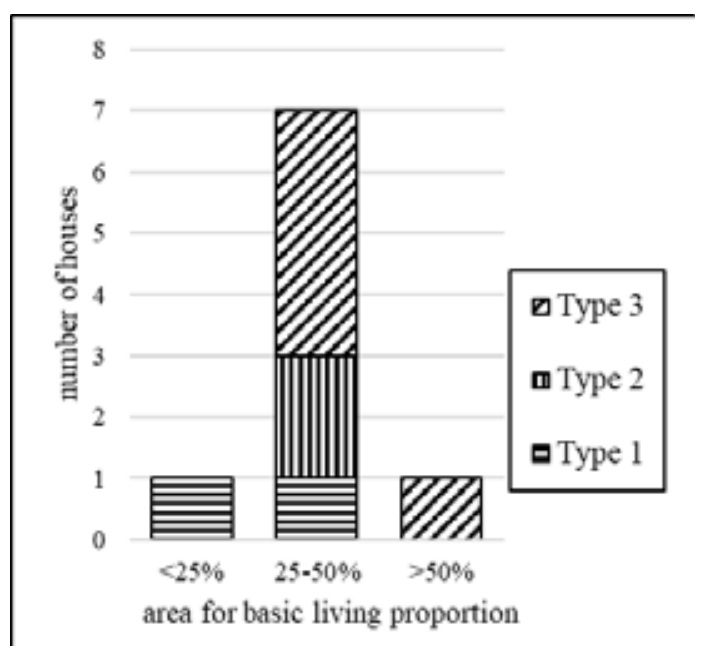

Figure 7. The proportion of area for basic living based on house type

Source: Data Analysis, 2020
Spatial observation of the house can be seen from the relationship between the position of the house in the field with the type of house and its orientation. Figure 8 shows that houses with type 3 , which means that the spaces are separated apart in various spots, have a distance of more than 5 meters away from the field. While type 1 and 2 are all found in a relatively very close range from the field, which is around 0-5 meters. This indicates that the house located very close to the field will occupy a site that tends to be flatter so that the arrangement of building units will be easier if it is built in a single unit or separate unit but in a relatively closer area. Whereas the house whose position is farther or more than the range of 5 meters tends to occupy the upward part of foothills and the site conditions are uneven. This causes parts of the site where houses are built to be steeper and contoured, making it more difficult to build houses in a single large mass of buildings. As a result, the house was formed in several distant units.

Overall houses that are located very close to the fields will have a part of wall that opens directly to the fields (figure 9). While the majority of the houses that farther away don't consider the fields as house orientation and tend to face the other direction. Rice field monitoring activities at houses that are located far from the fields cannot be done directly from inside the house so there is no urgency to face the house to the fields.

Both of the graphics (figure $8 \& 9$ ) indicate that house type and house orientation are affected by the position of the house occupying various site characters. This means that spatial character of houses on the flatter surfaces will be different from houses built on steeper sites.

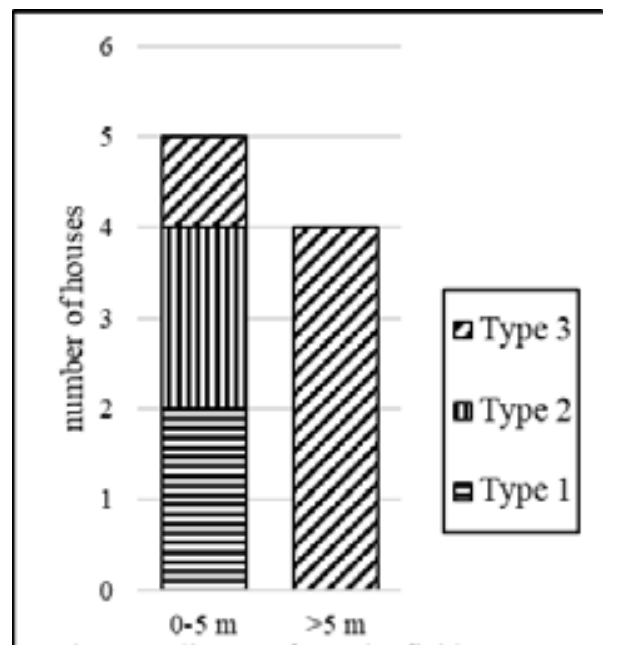

house's distance from the fields

Figure 8. Distance from the field based on house's type Source: Data Analysis, 2020 


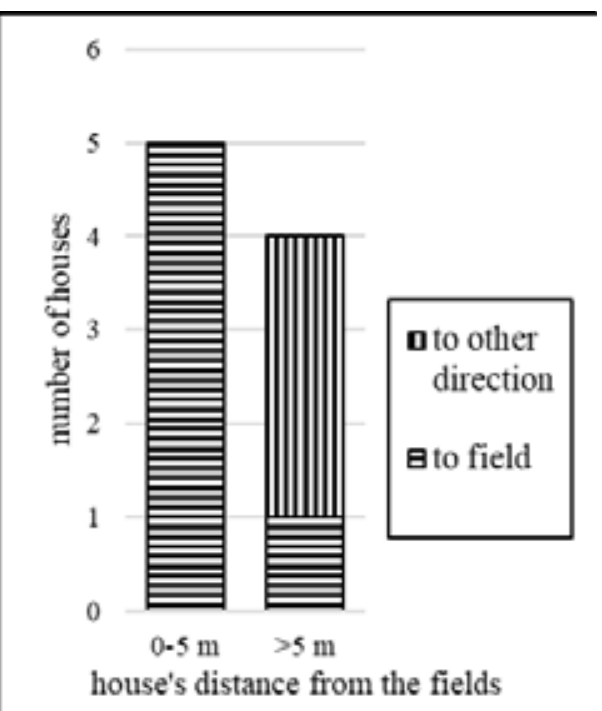

Figure 9. Distance from the field based on house orientation Source: Data Analysis, 2020

\subsection{Influencing Factor: Site as Determinant Aspect}

The findings illustrate that the layout arrangement of the houses tends to adjust to local site conditions. The decision to form the house in a single building unit or scattered pattern of several units is made based on land availability and proper conditions on the contour of karst hill. There is no evidence that the sun's path is used as a building orientation as all the houses don't face the same direction. As well as there is no cultural orientation used as consideration for arranging space like a limasan house for Javanese people which have saka guru as the main centre of the house (Slamet, 1985). Building orientation is only based on the position of the houses towards the fields where the houses which are close to the fields will be oriented towards them and the houses that are far oriented towards the other direction.

Here climate plays a little role when water resources depend on the rainy season there is a requirement for large water storage in order to supply water needs in the dry season. It is also based on the Gunung Sewu karst landscape's characteristics that don't have rivers or other water resources on the land surface.

\subsection{Influencing Factor: Economic Motive}

The proportion of the area used for basic living activities (sleep and cook) which less than 50\% indicates that the main needs of occupants are more for storage and keeping livestock. This means that what considered as important matters is survival function. The occupants need to protect their savings in the form of livestock and storage. To protect livestock, they need a place and food or water. To survive life in a year in order to eat rice they need to be present around their crop field, therefore, they live at omah alas.

Site indeed affects the house form but the initial decision to choose site as a living place is based on livelihood reason. It was the people who initially chose the site as the place where omah alas was built. The farmers prefer dry and hilly places as a place to live based on reasons to survive in these environmental conditions, farming in dryland is a possible opportunity to keep alive. This corresponds to what Rapoport has said that the choice of site depends largely on socio-cultural values (Rapoport, 1969). This economic motive, which is included in the socio-cultural domain, then plays a greater role compared to other factors.

The relation of the farmers and karst Gunung Sewu landscape is in symbiotic form. Nature is to be worked with and there was only little change in developing agricultural systems. Nature provides resources and when the resources are less, human will adapt to this condition by carrying out strategies that can be represented in omah alas.

\section{Conclusion}

Omah alas is physical evidence that occurs as a result of the relationship between the landscape and the people living in it. Omah alas accommodates the activities of its inhabitants who are farmers in karst area in the form of three zones of space functions: space for basic activities, space for storage, and space for livestock. The character of the of the houses is manifested in the spatial elements that are affected by the physical condition of the environment. Spatial characters that are affected by site are the layout of space and building orientation. Space and building layout is divided into 3 types of patterns that emerge due to differences in the character of the site where the houses were built. Omah alas that are closer to the field occupy flatter land so that they form type 1 (single unit) and type 2 (many adjacent units), both types are oriented to the fields. Houses that are further away from the fields (more than 5 meters away) occupy steeper land and form type 3 (multiple units that are far apart) and tend not to face the fields.

Site conditions have an influence on the spatial character of omah alas. Although the site is influential, however, the motivation of farmers in the first place to build houses near their rice field in the first place is a more main influence. The appearance of omah alas is based on the main factors which is to fulfil the necessities of life or economic reasons included in the socio-cultural domain.

\section{References}

Fatchurohman, H., Cahyadi, A., Nugraha, H. and Wacano, D. (2013) Strategi Adaptasi Masyarakat Terhadap Bencana Kekeringan di Kawasan Karst Kecamatan Panggang, Kabupaten Gunungkidul. Ekologi Lingkungan Kawasan Karst Indonesia: Menjaga Asa Kelestarian Kawasan Karst Indonesia. Editor Sudarmadji, E. Haryono, T. N. Adji, M. Widyastuti, R. Harini, E. Nurjani, A. Cahyadi, H. Nugraha. Cetakan 1, Yogyakarta: Deepublish.

Ford, D. and Williams, P. (2007) Karst Hydrogeology and Geomorphology. 2nd ed. England: John Wiley \& Sons, Ltd.

Habraken. (1988) Type as A Social Agreement. Asian Congress of Architects in Seoul, 1-18

Haryono, E., Adji, T.N., and Widyastuti, M. (2009) Environmental Problems of Telaga (Doline Pond) In Gunungsewu Karst, Java Indonesia. Proceedings of the 15th International Congress of Speleology, 1112-1116

Haryono, E., Barianto, D.H., and Cahyadi, A. (2017) Hidrogeologi Kawasan Karst Gunungsewu. Pekan Ilmiah Tahunan Perhimpunan Ahli Airtanah Indonesia, 1-33

Nibbering, J.W. (1997) Upland Cultivation and Soil Conservation in 
Limestone Regions on Java's South Coast. Paper Landscapes: Explorations in The Environmental History of Indonesia. Editor Boomgaard, P., F. Colombijn, and D. Henley. Leiden: KITLV Press. Norberg-Schulz. (1985) The Concept of Dwelling. 1st ed, New York: Rizzoli International Publications.

Rapoport, A. (1969) House Form and Culture. N. J.: Prentice-Hall, Inc.

Retnowati, A. (2014) Culture and Risk Based Water and Land Management in Karst Areas: An Understanding of Local Knowledge in Gunungkidul, Java, Indonesia. Thesis, Giessen: Faculty of Mathematic and Computer Science, Physics, Geography Institute for Geography, Justus Liebig University Giessen.

Slamet. (1985) Arsitektur Tradisional Daerah Jawa Tengah. Semarang: Direktorat Jendral Kebudayaan.

Toffin, G. (1994) Ecology and anthropology of traditional dwellings. Traditional Dwellings and Settlements Review, 5, 920

Uhlig, H. (1980) Man and Tropical Karst in Southeast Asia. Geojournal, 4 (1), 31-44

Wongphyat, W. and Suzuki, H. (2008) Spatial Analysis of Traditional Thai Dwellings in the Phrapradaeng District. Journal of Asian Architecture and Building Engineering, 7 (2), 225-232 